\title{
Measurement And Consequences Of U.S. Tourists' Perceptions Of Service Quality: A South African Hunting Safari Case Study
}

Xiliang Han, Nelson Mandela Metropolitan University, South Africa

Laetitia Radder, Nelson Mandela Metropolitan University, South Africa

\begin{abstract}
This research verifies the usefulness of the service quality principles and the Basic Service Package elements of the Augmented Service Offering model in measuring perceived service quality of a complex wildlife tourist activity. In addition, it determines the existence of a qualitysatisfaction and quality-intention link. The South African hunting safari serves as an illustrating example. As U.S. hunters constitute the largest cluster of non-domestic customers in the South African safari hunting industry, their perceptions of service quality and the resulting satisfaction and behavioral intentions can significantly impact the sustainable competitiveness and profitability of safari service providers. The results negate the applicability of the SERVQUAL model, but confirm the usefulness of the Augmented Service Offering model in measuring the service quality of the safari hunt and in identifying areas of service failure and adequate service performance. The regression analysis confirmed the existence of important quality-satisfaction and quality-intention links.
\end{abstract}

Keywords: basic service package; behavioral intention; hunting safari; perceived service quality; satisfaction; SERVQUAL

\section{INTRODUCTION}

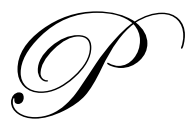

articipation in nature-based activities has become a major purpose of domestic and international tourism (Nyaupane, Morais and Graefe, 2004). Similar growth patterns are evident in wildlife tourism, a subset of nature-based tourism (Hall and Boyd, 2005). These trends are believed to be the result of increasing urbanization and a growing awareness of the environment which have stimulated a deeper appreciation for, and more regular visits to, natural areas.

Hunting makes an important contribution to South Africans' efforts of conserving nature, curbing environmental degradation and attracting wildlife tourists. Many ecological benefits are derived from financial incentives in wildlife ownership, management and conservation (Van der Waal and Dekker, 2000). For example, the bontebok, black wildebeest, Cape mountain zebra, geometric tortoises and numerous rare plant species were saved from extinction because of the actions of the country's hunting industry and private game ranch owners (Hamman, Lloyd and Stadler, 2005). In addition to saving wildlife species, hunting also contributes to preventing and reducing the costly impacts caused by the overpopulation of certain species (Mauser and Paddon, 2000) particularly in the absence of other predators, as happened with the elephant in certain conservation areas in South Africa. Antihunting lobbyists sometimes seem to forget that natural areas protected and managed for hunted species are also ideal for many non-hunted species that require similar habitats (Mauser and Paddon, 2000). Environments managed for hunting purposes thus support a higher diversity of wildlife than do unmanaged areas.

These actions enhance the country's diversity of wildlife resources and its already highly-acclaimed trophy hunting industry. Trophy hunting (also known as sport or safari hunting) refers to legitimate and organized hunting activities undertaken by individuals whose primary objective is securing trophies from killed animals, birds and 
reptiles (Report to the Minister of Environmental Affairs and Tourism, 2005). This form of hunting is mostly undertaken by visiting tourists, most from the United States (Radder, 2003).

Trophy hunters make an important contribution to South Africa's economic and social welfare. Because of trophy hunting, the country's game ranching and safari hunting industry has developed into a multi-million rand industry, with R730 million (US\$91.2 million) resulting directly from daily rates, trophy fees and taxidermy work (Professional Hunters' Association of South Africa, 2009). This amount excludes indirect contributions to other parts of the economy, such as airlines, pre-and post-safari accommodation and shopping (Damm, 2005). Examples of social benefits derived from trophy hunting are an estimated 70000 direct jobs and the development of infrastructure in rural areas (Professional Hunters' Association of South Africa, 2009). Given the important impact of the South African hunting safari, the importance of the sustainability of this form of tourism is evident.

In South Africa, trophy hunting occurs mainly on privately-owned ranches (Von Brandis and Reilly, 2007). However, various independent, yet interdependent organizations contribute to providing safari hunters with a bundle of services spanning the pre-safari stage, peak participation stage and the post-safari stage. A South African hunting safari typically commences with the engagement of a South African hunting outfitter who arranges the safari, deals with landowners and obtains the required hunting permits (Professional Hunters' Association of South Africa, 2010). Since the outfitter is not responsible for the international travel, these services are usually provided by a travel agent or an on-line service provider. After arrival in South Africa, clients are serviced by professional hunters who see to all aspects of the actual hunt, and by trackers, skinners and lodge staff, in addition to services provided by the outfitter. Services in the post-safari stage are provided by taxidermists who prepare the trophy, and by those involved with the return flight. However, given the length and depth of the interaction between the different parties, the primary and most direct service providers are the hunting outfitters, professional hunters, trackers, skinners and lodge staff involved in service delivery at the destination level.

Given its service-driven nature, the hunting safari has much in common with tourist behavior and servicerelated challenges experienced by other tourism industries. Service quality, satisfaction and behavioral intentions have been identified as the central concepts in the study of tourist behaviour (Baker and Crompton, 2000; Yuan and Jang, 2008) and hence are of particular importance. It is generally believed that high service quality and resulting satisfaction lead to positive word-of-mouth endorsements, referrals and repeat visits (Žabkar, Brenčič and Dmitrović, 2010), which ultimately affect the competitiveness and profitability (Chi and Qu, 2008; Gilbert and Wong, 2003) of suppliers associated with the tourist activity.

Despite wide ranging research into the relationship between quality, satisfaction and behavioral intentions, this phenomenon has hardly been investigated in the context of the international or the South African hunting safari. This is surprising given the importance of hunting in a South African context and the intense competition among service providers.

The purpose of our research is twofold: firstly, to measure U.S. safari hunters' perceptions of service quality and secondly, to explore the relationship between perceptions of service quality, satisfaction and behavioral intentions. In order to formulate testable hypotheses, we provide a brief review of the determinants, measurement and consequences of service quality with the purpose of establishing a conceptual basis for our arguments.

\section{LITERATURE REVIEW}

\section{Determinants Of Service Quality}

In contrast with the objective focus of manufacturer-oriented definitions of quality, a customer-oriented approach underlies the concept of quality within a service context (Williams and Buswell, 2003). Service quality is frequently defined as "the degree and direction of discrepancy between consumers' perceptions and expectations" (Parasuraman, Zeithaml and Berry, 1988), expressed as an expectancy disconfirmation measure (Oliver, 1980). In following the arguments in theory, safari hunters' expectations will be confirmed, and service performance regarded as satisfactory, if perceptions equal expectations. If perceptions exceed expectations, the latter are positively disconfirmed and service performance is regarded as highly satisfactory. Dissatisfaction is associated with a negative disconfirmation resulting from perceptions falling below expectations (Hoffman and Bateson, 2006). 
Since expectations and perceptions are unique to each individual, the term perceived service quality would be a more appropriate description (Baron, Harris and Hilton, 2009). The disconfirmation-based service quality model can be diagrammatically illustrated as in Figure 1.

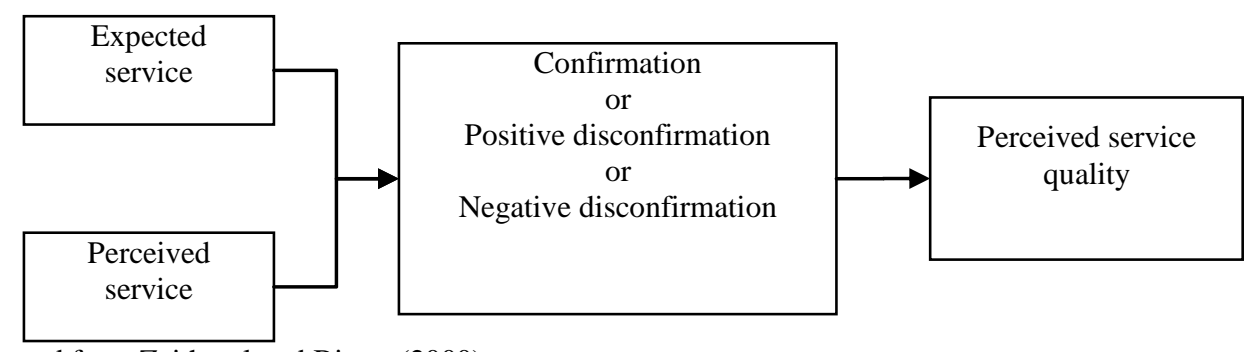

Source: Adapted from Zeithaml and Bitner (2000)

Figure 1: The Disconfirmatory Perceived Hunting Service Quality Model

It follows from Figure 1 that expectations and perceptions act as core antecedents to perceived service quality. Expectation, the first antecedent, is formed before or during the delivery of a service (Mudie and Pirrie, 2006) and represents "what customers predict about the occurrence of the service (will happen) and what customers believe about the capability of the provider (should happen)" (Coye, 2004). In other words, safari hunters' expectations are impacted by what they predict will happen and their views about the capability of the service providers such as the outfitter, professional hunter and supporting staff.

The definition of expectations indicates the existence of two principal conceptualizations. The first, consistent with the customer satisfaction literature, regards expectations as "predictions made by customers about what is likely to happen during an impending transaction or exchange" (Zeithaml, Berry and Parasuraman, 1993), while the second, dominant in the service quality literature, views expectations as "what customers believe a service provider should offer rather than would offer" (Coye, 2004). The latter approach to the definition of expectations; namely, the desires or wants of U.S. hunters, is used in the current study.

Customer perception, the second core antecedent of perceived service quality (see Figure 1), is rooted in psychology and cognitive sciences (Hsu, Killion, Brown, Gross and Huang, 2008) and describes the "process by which an individual selects, organizes and interprets stimuli into a meaningful and coherent picture" (Schiffman and Kanuk, 1987). Reisinger and Turner (2003) categorize perceptions as those of other people (e.g. tourist perceptions of hosts), own perceptions (e.g. tourist perceptions of themselves) and perceptions of the perceptions of others (e.g. tourist perceptions of how they are perceived by hosts). The present study investigates the first type of perceptions; namely, U.S. hunters' perceptions of the service delivery of South African safari hosts.

\section{Measurement of Service Quality}

Given the importance of customers' perceptions of quality in a service context, it is no surprise that numerous studies have been devoted to its measurement (Ladhari, 2008). Examples of service quality models include the Nordic model (Grönroos, 1984; 2007); SERVPERF (Tse and Wilton, 1988; Cronin and Taylor, 1992); and SERVQUAL (Parasuraman et al., 1988). SERVQUAL is probably the most commonly used model for diagnosing service quality shortfalls and developing service quality strategies (Chen, 2008). This model has been applied and examined across a variety of tourism and leisure contexts and is hence described in more detail. 


\section{SERVQUAL}

The SERVQUAL instrument comprises two sets of 22 statements each, measured on a similar seven-point Likert-type scale and aims to produce gap scores in the range of -6 to +6 (Williams and Buswell, 2003). The 22 statements are customarily grouped into five service dimensions, that is, tangibles, reliability, responsiveness, assurance and empathy (Parasuraman et al., 1988).

SERVQUAL has been used within a tourism and leisure context in terms of the quality of tourist services (Masmanidis, Vassiliadis and Mylonakis, 2006) such as those of tour operators (Atilgan, Akinci and Aksoy, 2003); tourism destinations (Chand, 2010; López-Toro, Dỉaz-Muñoz and Pérez-Moreno, 2010); outdoor adventure tourism, for example watersports (Donne, 2009), kayaking, orienteering and archery (Kouthouris and Alexandris, 2005), and in a wildlife setting (Akama and Kieti, 2003). The model's application resulted in various derivatives of the instrument for different tourism-related service contexts, such as LQI for hotels (Getty and Getty, 2003), DINESERV for restaurants (Stevens, Knutson and Patton, 1995), ECOSERV for ecotourism (Khan, 2003), HISTOQUAL for historical sites (Frochot and Hughes, 2000) and ADVENTUREQUAL for outdoor adventure activities (Donne, 2009).

Despite its wide use across industries, the SERVQUAL model has also been criticized by several researchers (e.g. Buttle, 1996; Cronin and Taylor, 1992; Teas, 1993) particularly with respect to conceptual and operational aspects. However, in a counter-feat, Ladhari (2008) summarized 30 recent industry-specific measures of service quality and concluded that only one measure, INDSERV (Gounaris, 2005), has been empirically demonstrated to outperform SERVQUAL.

The SERVQUAL model thus still seems to have its place, provided a number of caveats are recognized. These particularly relate to the use of the disconfirmation paradigm and the generalizability of the model. Cronin and Taylor (1992), for example, postulate that service quality should be conceptualized as an attitude and that the estimation of perceptions by customers might already include a perception-minus-expectation mental process. Others (e.g. Crompton and Love, 1995; Cronin and Taylor, 1992; Hui, Wan and Ho, 2007) argue that perception scores have a stronger correlation with dependent measures (e.g. overall quality and satisfaction) than disconfirmation scores do. Although the disconfirmation-debate continues, it seems to be generally accepted in the literature that:

- the disconfirmation specification is proper if the research purpose is to diagnose service quality shortfalls; and

- the perception-only specification is appropriate if the purpose is to explain variance in dependent variables (Parasuraman, Zeithaml and Berry, 1994).

When Parasuraman et al. (1988) initially developed SERVQUAL based on data from five service industries, their aim was to provide a generic instrument applicable in all service settings (Ladhari, 2008). However, several studies (e.g. Babakus and Boller, 1992; Carman, 1990) have experienced difficulties in replicating SERVQUAL across industries because the number and nature of service dimensions is ambiguous. Generalizability thus remains problematic.

Given the wide use of SERVQUAL, the large service element contained in the hunting safari and the absence of the need to generalize, the model was deemed potentially useful for the research at hand. Furthermore, as no evidence of the application of SERVQUAL or an adapted version thereof to the African hunting safari could be traced, we had no reason to believe that the model would not be appropriate. However, in applying SERVQUAL to our research, cross-loading of items and overlapping of dimensions negatively affected the reliability and validity of the entire instrument. This confirmed that a simple adaptation of the SERVQUAL items was insufficient for measuring the service quality associated with the hunting safari.

Given that the unsatisfactory results derived from our application of the SERVQUAL model support the notion by Carman (1990) and Caro and García (2008) that another industry-specific measurement scale, embodying 
the unique characteristics of the specific industry, is required, we investigated the usefulness of the Basic Service Package elements of the Augmented Service Offering (ASO) model to measuring hunters' perceptions of service quality.

\section{The Basic Service Package}

The ASO model proposed by Grönroos (1987) aims at understanding services and customers' perceptions of service quality. Apart from Ozment and Morash (1994), who provided empirical evidence of the close relationships between the ASO model and perceived service quality in the airline industry, little research (e.g. Sanghera, Chernatony and Brown, 2002) seems to have responded to the call for additional confirmatory studies in other service settings. By applying the central part (i.e. the Basic Service Package) of the ASO model to U.S. hunters' perceptions of service quality, we contribute to further research on the ASO model.

The basic service package is the bundle of services needed to fulfil the needs of target customers (Grönroos, 2007). These services are categorized into core and peripheral services. Core services reflect the reason why the business participates in the market and why customers buy from it (Grönroos, Heinonen, Isoniemi and Lindholm, 2000). Peripheral services, on the other hand, comprise facilitating and supporting services. Facilitating services act as prerequisites in the purchase and consumption of the core service, as without these services the core service will not be affected. In contrast, supporting services are discretionary and are used to enhance the attractiveness and competitiveness of the core service (Grönroos et al., 2000). Grönroos (2007) warns that an overlap might exist between facilitating and supporting services.

Service quality evaluation is affected by the presence or absence of the expected core and peripheral service elements and by the extent to which each element meets expected standards (Normann, 2000). In the trophy hunting setting, core services might include the abundance of game, and field guidance by knowledgeable and welltrained staff; facilitating services might relate to the timeliness of service and empathy in dealing with the client. Accommodation and catering are examples of supporting services.

Following from the preceding discussion, the first set of hypotheses was formulated as follows:

H1a: There is a statistically significant, positive disconfirmation between U.S. hunters' perceptions and expectations with respect to core services.

H1b: There is a statistically significant, positive disconfirmation between U.S. hunters' perceptions and expectations with respect to facilitating services.

H1c: There is a statistically significant, positive disconfirmation between U.S. hunters' perceptions and expectations with respect to supporting services.

H1d: There is a statistically significant, positive disconfirmation between U.S. hunters' perceptions and expectations with respect to overall services.

\section{Consequences Of Service Quality}

Although in practice service quality and customer satisfaction are often used interchangeably, studies in services marketing have shown that they are distinct constructs (Chen, 2008). Some researchers (e.g. Zeithaml and Bitner, 2000) view service quality as a necessary but not sufficient condition to establish customer satisfaction. In addition, product quality, price, situational factors (e.g. weather conditions) and personal factors (e.g. emotional states) can also influence satisfaction levels. Other researchers (e.g. Cronin, Brady and Hult, 2000) describe service quality as a cognitive response to a service experience, and satisfaction as an affective response to that experience. However, in terms of the interrelationship between the two concepts, literature seems to agree that service quality is antecedent to customer satisfaction, especially in a tourism context (e.g. Petrick, 2004; Yuan and Jang, 2008).

In addition to the quality-satisfaction link, exploration of the quality-intention link has also emerged in recent literature (Hutchinson, Lai and Wang, 2009). Zeithaml, Berry and Parasuraman (1996) propose that customers' perceptions of service quality might correlate with five favourable behavioral intentions to a specific service provider. These are to say positive things about the provider; recommend the provider to other customers; remain loyal to the provider; spend more with the provider; and pay price premiums. A number of tourism studies 
have used one or more of these constructs to examine the outcomes of service quality. Petrick (2004), for example, finds that cruise passengers' perceptions of service quality have a direct effect on their behavioral intentions. Žabkar et al. (2010) report a similar cause-and-effect relationship in the tourist-destination context. However, Hutchinson $e t$ al. (2009) suggest that the quality-intention link is not applicable to golf travellers.

Since the quality-satisfaction and the quality-intention interfaces have not yet been tested for the South African hunting safari, the second research question was hypothesized as follows:

H2a: Perceived quality of core, facilitating and supporting services has a statistically significant effect on U.S. hunters' satisfaction.

H2b: Perceived quality of core, facilitating and supporting services has a statistically significant effect on U.S. hunters' intentions to revisit.

H2c: Perceived quality of core, facilitating and supporting services has a statistically significant effect on U.S. hunters' word-of-mouth referrals.

\section{RESEARCH METHODOLOGY}

\section{Data Collection And Sampling}

The empirical study used a self-administered mail survey to collect the raw data. This approach was chosen because of the advantages it offers; namely, that respondents may complete the survey in their own time and at their own pace, the low cost per survey, and the absence of interviewer bias given the non-involvement of a human or mechanical agent (Burns and Bush, 2006). A mail survey was preferred because of the extensive and hard-to-reach geographical area covered by the research (Smith and Martins, 1996). Radder (2003) indicates that the largest proportion of hunters who engage in the South African safari live in the U.S. and reside within a rural environment.

With the assistance of an official facilitator in the industry, 2000 survey packages (each comprising a questionnaire and a postage-paid reply envelope) were sent to potential respondents who had participated in the South African hunting safari in recent years. By the due date, 236 useable questionnaires were returned, 154 of which originated from the U.S. This yielded a tolerable overall response rate of 13.2\% (Dillon, Madden and Firtle, 1994).

Table 1 reports the demographic characteristics of the respondents. The vast majority was male, between 40 and 60 years old, and lived in the countryside at the time of the survey. Proportionately more respondents grew up in rural areas compared with urban areas. The largest proportion had an annual household income of less than US $\$ 100,000$ and a higher education of one to four years.

Table 1: Demographic Profile Of The U.S. Respondents $(n=154)$

\begin{tabular}{|l|c|c|c|}
\hline \multirow{2}{*}{ Variable } & Category & Frequency & Percentage \\
\hline \multirow{2}{*}{ Agender } & Male & 148 & 96.1 \\
\cline { 2 - 4 } & Female & 6 & 3.9 \\
\hline \multirow{2}{*}{ Current home environment } & $<40$ or $>60$ years old & 57 & 63.0 \\
\cline { 2 - 4 } & $40-60$ years old & 97 & 30.5 \\
\hline \multirow{2}{*}{ Childhood home environment } & Urban & 47 & 69.5 \\
\hline \multirow{3}{*}{ Annual household income } & Rural & 107 & 44.2 \\
\cline { 2 - 4 } & Urban & 68 & 55.8 \\
\hline \multirow{3}{*}{ Post-school education } & Rural & 66 & 40.3 \\
\cline { 2 - 4 } & US\$100,000- US\$200,000 & 52 & 35.0 \\
\cline { 2 - 4 } & $>$ US\$200,000 & 38 & 24.7 \\
\cline { 2 - 4 } & None & 19 & 42.3 \\
\cline { 2 - 4 } & $1-4$ years & 73 & 40.3 \\
\cline { 2 - 4 } & $>4$ years & 62 & 47.4 \\
\hline
\end{tabular}




\section{Instrument Development And Purification}

An initial pool of statements embodying the three major elements of the safari service package was generated by a review of relevant academic literature, promotional material, governmental reports, a diary written by an U.S. hunter on his South African safari, as well as by interviews with primary safari providers. Oh (2001) suggests that involving managers and tourists in the early process of quality-related research is preferable, especially for identifying strategically important attributes. This preliminary sample of statements was then refined into a $25-$ item list by a panel of experts from academia and industry. The respondents were asked to use a six-point forcedchoice Likert scale (Hair, Bush and Ortinau, 2006) to rate their expectations (1=totally unimportant and 6=extremely important) and perceptions ( $1=$ strongly disagree and $6=$ strongly agree) of the 25 quality attributes.

Exploratory factor analysis was performed in SPSS Version 15 to purify the measuring instrument using the gap (perception minus expectation) scores of all 236 respondents. This implies that the resultant factor structure was applicable to both U.S. and non-U.S. samples. Principal components analysis was used at the factor extraction stage and the Direct Oblimin technique at the factor rotation stage of the analysis. Seventeen items were retained due to their practically significant loadings exceeding 0.5 (Hair, Black, Babin, Anderson and Tatham, 2006). These items constituted an anticipated three-factor structure (i.e. core services, facilitating services and supporting services). The results of the reliability analysis supported the internal consistency of each resultant factor.

\section{HYPOTHESIS TESTING AND DISCUSSION}

\section{The Gap Analysis of Perceived Service Quality}

Descriptive analysis and a paired-samples t-test were performed to address the first research question and corresponding hypotheses (H1a, H1b, H1c and H1d). Table 2 provides a full exposition of the levels of service quality perceived by U.S. hunters in terms of perception and expectation mean scores and standard deviations, gap scores, and t-values of 17 observable attributes (items), three latent factors, and an overall-quality measure. In each factor, the items assigned are presented according to the size of gap scores.

Core services grouped together seven attributes (see Table 2) reflecting the basic benefits sought from the safari and the primary reason for the hunter-provider service transaction. Two attributes (Q20 and Q25) were notable in terms of mean scores. Q25 had the lowest perception mean score $(\mathrm{M}=5.09)$, not only in this factor but among all 17 items. This indicates that U.S. hunters considered the projection of a 'wilderness feeling' by facilities as the worst aspect of the provider's performance with respect to service attribute delivery. In addition, Q20 had the highest expectation mean score $(\mathrm{M}=5.61)$, not only in this factor but among all the items. Hence, the competency of field guidance was the most important indicator of service quality.

Although not statistically significant, it was also found that five of the seven items (Q9, Q7, Q8, Q24 and Q25) in this factor had a negative gap score. These attributes represent the service shortfalls that require providers' attention in terms of improvement. Finally, it is clear that the factor gap was positive $(+0.05)$ but not statistically significant ( $\mathrm{t}=0.69)$, suggesting that $\mathrm{H} 1 \mathrm{a}$ be rejected.

Facilitating services comprised seven attributes (see Table 2) describing the skills and abilities required by safari staff to successfully interact with clients during the delivery of the core service. From a customer's perspective, it could be argued that inferior delivery on these attributes may hinder or even prevent effective consumption of the core service. 
Table 2: Comparison of Respondents' Perceptions and Expectations

\begin{tabular}{|c|c|c|c|c|}
\hline Factor and item & Perception & Expectation & Gap & T-value \\
\hline Factor one: Core services & $5.39(0.89)$ & $5.34(0.66)$ & 0.05 & 0.69 \\
\hline Q22: Environmental appropriateness of facilities & $5.41(0.95)$ & $4.99(1.01)$ & 0.42 & $4.56 * * *$ \\
\hline Q20: Field guidance provided by staff & $5.62(0.97)$ & $5.61(0.71)$ & 0.01 & 0.08 \\
\hline Q09: Abundance of game & $5.34(1.00)$ & $5.38(0.82)$ & -0.04 & 0.48 \\
\hline Q07: Knowledgeable staff & $5.45(1.08)$ & $5.50(0.72)$ & -0.05 & 0.60 \\
\hline Q08: Well-trained staff & $5.41(1.10)$ & $5.49(0.73)$ & -0.08 & 0.88 \\
\hline Q24: Staff's ethical standards & $5.44(1.10)$ & $5.54(0.76)$ & -0.10 & 1.19 \\
\hline Q25: 'Wilderness feeling' of facilities & $5.09(1.24)$ & $4.90(1.16)$ & -0.20 & 1.83 \\
\hline Factor two: Facilitating services & $5.31(1.00)$ & $5.13(0.83)$ & 0.19 & $2.27 *$ \\
\hline Q16: Personal attention & $5.34(1.02)$ & $4.81(1.12)$ & 0.53 & $5.79 * * *$ \\
\hline Q15: Prompt service & $5.37(1.02)$ & $5.08(0.94)$ & 0.29 & $3.31 * *$ \\
\hline Q14: Staff's social skills & $5.20(1.21)$ & $4.94(1.03)$ & 0.26 & $2.41 *$ \\
\hline Q18: Understanding of client's needs & $5.31(1.14)$ & $5.09(1.02)$ & 0.21 & $2.17 *$ \\
\hline Q17: Having client's best interests at heart & $5.36(1.11)$ & $5.31(0.88)$ & 0.05 & 0.57 \\
\hline Q11: Services provided timeously & $5.38(1.09)$ & $5.35(0.83)$ & 0.03 & 0.35 \\
\hline Q13: A sincere interest in solving client's problems & $5.24(1.18)$ & $5.32(0.93)$ & -0.08 & 0.76 \\
\hline Factor three: Supporting services & $5.60(0.67)$ & $5.08(0.87)$ & 0.51 & $7.31 * * *$ \\
\hline Q03: Comfortable accommodation & $5.58(0.81)$ & $4.93(1.06)$ & 0.66 & $7.41 * * *$ \\
\hline Q05: Excellent meals and refreshments & $5.54(0.77)$ & $5.09(0.88)$ & 0.45 & $5.69 * * *$ \\
\hline Q04: Clean accommodation & $5.66(0.67)$ & $5.23(0.93)$ & 0.44 & $5.95 * * *$ \\
\hline Overall & $5.40(0.83)$ & $5.21(0.69)$ & $\mathbf{0 . 1 9}$ & $2.82 * *$ \\
\hline
\end{tabular}

Note: $* \mathrm{p}<0.05 ; * * \mathrm{p}<0.01 ; * * * \mathrm{p}<0.001$

All the perception mean scores in this factor had a relatively high standard deviation (>1), denoting the existence of relatively high discriminant power. Consequently, these attributes are ideal variables for classifying U.S. hunters in terms of their actual experiences. Furthermore, Q16 had the lowest expectation mean score $(\mathrm{M}=4.81)$ not only in this factor but among all the items, implying that visitors deemed the availability of personalized service attention to be the least important indicator of quality. Q13 had, albeit not statistically significant, the only negative gap score $(-0.08)$ in this factor, indicating another area of service failure. Finally, it was found that the factor gap was positive $(+0.19)$ and statistically significant $(\mathrm{t}=2.27$; $\mathrm{p}<0.05)$. Hence, H1b was not rejected.

Supporting services gathered three attributes (see Table 2) relating to accommodation and catering aspects of the safari service. These attributes were not essential for the delivery of the core service, but acted as value-added elements to make the package more attractive and competitive. Q4 had the highest perception mean score $(\mathrm{M}=5.66)$ not only in this factor but among all the items, implying that U.S. hunters were most impressed by the accommodation's level of cleanliness.

All three attributes had positive and statistically significant gap scores. Q3 had the largest gap $(+0.66$; $\mathrm{t}=7.41 ; \mathrm{p}<0.001$ ) not only in this factor, but among all the items. Finally, since the factor gap score was positive $(+0.51)$ and statistically significant $(\mathrm{t}=7.31 ; \mathrm{p}<0.001), \mathrm{H} 1 \mathrm{c}$ was not rejected.

In summary, at the item level, the perception mean scores ranged from 5.09 to 5.66; the expectation mean scores ranged from 4.81 to 5.61. Given the use of a six-point Likert scale, U.S hunters had above average perceptions and expectations of all the attributes. Figure 2 illustrates the service gaps at factor level. It is evident that the factor mean scores on perceptions were consistently higher than those on expectations, implying that U.S. hunters' expectations of the South African hunting safari service were positively disconfirmed. In other words, safari providers were successful in meeting U.S. hunters' expectations. In addition, the statistical results showed that the overall gap score was +0.19 at the significance level of 0.01 (see Table 2). H1d was thus not rejected. 


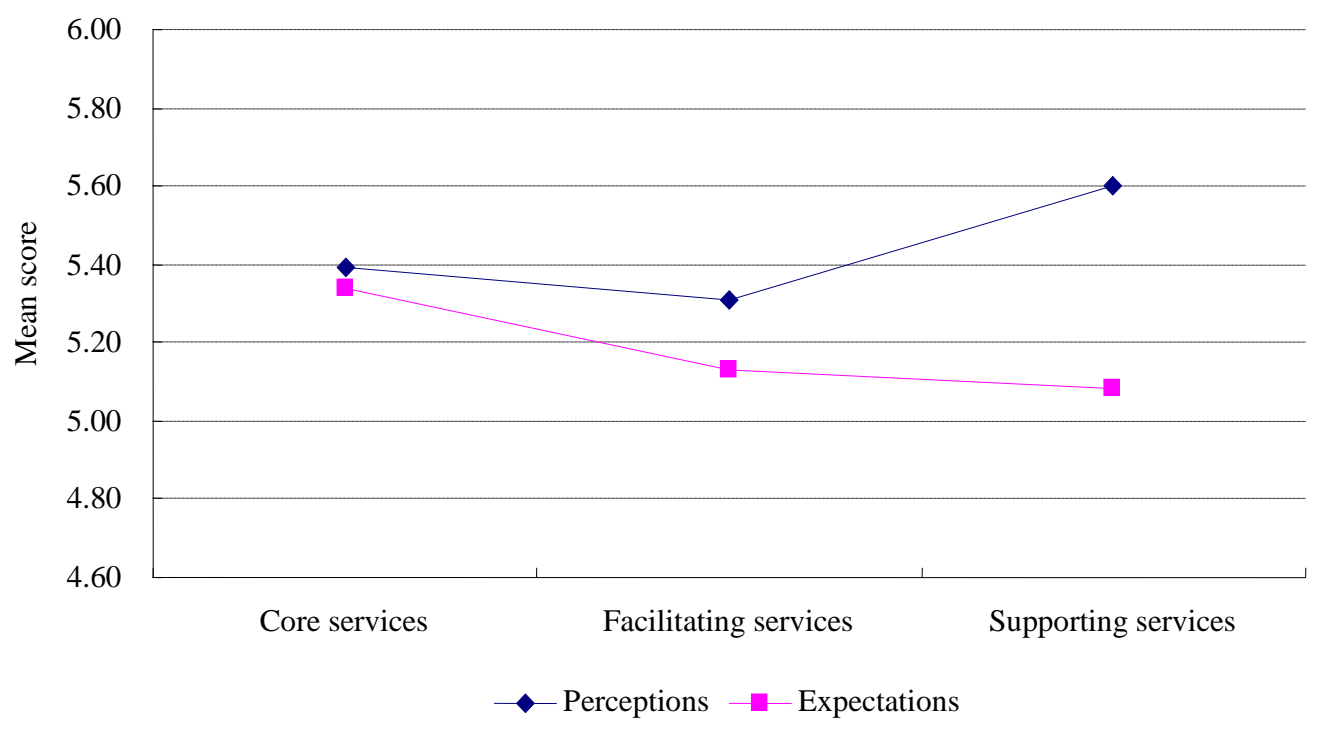

Figure 2: Comparison of Factor Mean Scores

\section{The Outcomes of Perceived Service Quality}

Three separate standard-type multiple regression analyses were performed to address the second research question and verify hypotheses $\mathrm{H} 2 \mathrm{a}, \mathrm{H} 2 \mathrm{~b}$ and $\mathrm{H} 2 \mathrm{c}$. This allowed for inspecting the predictability power of the three service-quality factors in terms of the hunters' satisfaction, intentions to revisit and word-of-mouth (WOM) referrals.

In contrast with hierarchical and stepwise approaches, the standard approach, the most commonly used regression analysis method, allows for simultaneously entering all the independent variables into the equation (Pallant, 2007). It has to be noted that only perception mean scores (instead of expectation mean scores or gap scores) were brought into the regression analysis process. This decision was made based on the argument that the perception scale is preferable if the research purpose is to predict dependent variables rather than to uncover service failures (Parasuraman et al., 1994).

To investigate whether perceived service quality could influence satisfaction, the factor mean scores on perceptions regressed on a single-item satisfaction measure using a six-point Likert scale; namely, "I had a positive overall hunting experience during the South African safari". The mean score of this measure was $5.21(\mathrm{SD}=0.91)$, denoting that U.S. hunters were generally satisfied with the South African safari. A preliminary investigation was done to ensure that no violation of the assumptions on multicollinearity, normality, linearity and homoscedasticity exists. This suggests that the results shown in Table 3 were truly representative of the sample.

Table 3: Impact of Perceived Service Quality on Satisfaction

\begin{tabular}{|l|c|c|c|c|}
\hline \multicolumn{1}{|c|}{ Dependent variable } & Independent variable & B & Beta & T-value \\
\hline & Intercept & 1.566 & $3.141^{* *}$ \\
\hline Satisfaction & Core services & 0.386 & 0.377 & $2.589 *$ \\
\hline$\left(\mathrm{R}^{2}=0.379 ; \mathrm{F}=30.490^{* * *}\right)$ & Facilitating services & 0.177 & 0.194 & 1.754 \\
\hline & Supporting services & 0.112 & 0.083 & 0.733 \\
\hline
\end{tabular}

Note: ${ }^{*} \mathrm{p}<0.05 ; * * \mathrm{p}<0.01 ; * * * \mathrm{p}<0.001$ 
At the model level, the linear combination of the three factors of service quality was statistically significantly related to satisfaction $\left(R^{2}=0.38 ; F=30.49 ; p<0.001\right)$. At the variable level, however, core services was the sole independent variable making a statistically significant contribution to the prediction of satisfaction ( $\mathrm{t}=2.589$; $\mathrm{p}<0.05)$. Hence, H2a was partially rejected.

The second multiple regression analysis was conducted to investigate the influence of the three servicequality factors on revisit intention of U.S. hunters as shown in Table 4. The latter was measured by a single six-point Likert scale; namely, "I will return to South Africa for another hunting experience". The mean score of this scale was $5.12(\mathrm{SD}=1.31)$, implying that U.S. hunters' willingness to revisit South Africa for another hunting safari was generally high. The preliminary investigation provided no evidence of violation of any assumption attached to regression analysis.

Table 4: Impact of Perceived Service Quality on Revisit Intention

\begin{tabular}{|l|c|c|c|c|}
\hline \multicolumn{1}{|c|}{ Dependent variable } & Independent variable & B & Beta & T-value \\
\hline & Intercept & 4.188 & $5.047 * * *$ \\
\hline Revisit intention & Core services & 0.938 & 0.634 & $3.784 * * *$ \\
\hline$\left(\mathrm{R}^{2}=0.175 ; \mathrm{F}=10.578^{* * *}\right)$ & Facilitating services & 0.083 & 0.063 & 0.496 \\
\hline & Supporting services & 0.816 & 0.418 & $3.199 * *$ \\
\hline
\end{tabular}

Note: $* * \mathrm{p}<0.01 ; * * * \mathrm{p}<0.001$

At the model level, the linear combination of the three factors of service quality statistically significantly explained $17.5 \%$ of the variation in revisit intention $(\mathrm{F}=10.58 ; \mathrm{p}<0.001)$. However, the amount of the variation explained was deemed low, as the literature suggests that survey data generally produce $\mathrm{R}^{2}$ in the range of 0.3 to 0.5 (Lehmann, 2006). Therefore, it could be alleged that the correlation between perceived service quality and revisit intention was valid, but not reliable. At the variable level, both core services $(t=3.784 ; \mathrm{p}<0.001)$ and supporting services $(\mathrm{t}=3.199 ; \mathrm{p}<0.01)$ made a statistically significant contribution to the prediction of revisit intention. This suggests that $\mathrm{H} 2 \mathrm{~b}$ was partially rejected.

To test the potential impact of U.S. hunters' perceived service quality on their intentions to verbal recommendation, the third multiple regression analysis was performed by correlating the service-quality factor scores with a single-item WOM intention measure using a six-point Likert scale; namely, "I will recommend South Africa to my family and/or friends wanting a hunting experience" (Table 5). The mean score of this measure was $5.26(\mathrm{SD}=1.54)$, indicating a relatively high likelihood of U.S. hunters recommending South Africa as an ideal safari destination. The preliminary investigation showed no violation of any assumption of regression analysis.

In terms of the regression model, the linear combination of the three factors of service quality was statistically significantly related with WOM intention $\left(\mathrm{R}^{2}=0.30 ; \mathrm{F}=21.40 ; \mathrm{p}<0.001\right)$. Concerning individual independent variables, the results showed that WOM referrals could be statistically significantly predicted by any of the three service-quality factors; namely, core services $(\mathrm{t}=3.012 ; \mathrm{p}<0.01)$, facilitating services $(\mathrm{t}=2.697 ; \mathrm{p}<0.01)$ and supporting services $(\mathrm{t}=2.369 ; \mathrm{p}<0.05)$. Hence, $\mathrm{H} 2 \mathrm{c}$ was not rejected.

Table 5: Impact of Perceived Service Quality on WOM Intention

\begin{tabular}{|l|c|c|c|c|}
\hline \multicolumn{1}{|c|}{ Dependent variable } & Independent variable & B & Beta & T-value \\
\hline & Intercept & 1.961 & $2.186^{*}$ \\
\hline WOM intention & Core services & 0.807 & 0.465 & $3.012^{* *}$ \\
\hline$\left(\mathrm{R}^{2}=0.300 ; \mathrm{F}=21.398^{* * *}\right)$ & Facilitating services & 0.489 & 0.317 & $2.697 * *$ \\
\hline & Supporting services & 0.653 & 0.285 & $2.369^{*}$ \\
\hline
\end{tabular}

Note: $* \mathrm{p}<0.05 ; * * \mathrm{p}<0.01 ; * * * \mathrm{p}<0.001$ 


\section{SUMMARY, CONCLUSIONS AND MANAGERIAL IMPLICATIONS}

The South African hunting safari is a highly-acclaimed tourist offering that makes an appreciable addition to the country's international tourist arrivals, a considerable direct contribution to its game ranching industry, and an important indirect contribution to nature conservation. U.S. hunters constitute the largest cluster of these customers.

To make sense of the extent of the sustainable competitiveness and profitability of South African safari providers, we set two major objectives in this research; namely, to measure perceived service quality and to examine its causal relationships with satisfaction and behavioral intentions.

The results of the theoretical and empirical studies point to the following core conclusions. With respect to our first research objective, measuring U.S. safari hunters' perceptions of service quality, it was anticipated that perceived service quality could be effectively measured by SERVQUAL or its derivatives. However, the application of the model to the South African safari did not yield satisfactory results. This implies that SERVQUAL cannot be used to effectively measure the quality of the South African hunting safari. Our findings thus support the notion that the number and components of the service quality dimensions are not generic to all services, but dependent upon the particular service being offered (Akbaba, 2006).

Since the SERVQUAL model did not seem useful for the current research, we verified the potential usefulness of the ASO model, and specifically its Basic Service Package elements, to measuring perceived service quality in the hunting tourism industry. Our results confirmed the presence of three anticipated factors (core services, facilitating services and supporting services). These factors comprised 17 service attributes with practically significant loadings exceeding 0.5. Core services grouped together attributes reflecting the basic benefits sought from the safari and the primary reason for the hunter-provider service transaction. Facilitating services related to the skills and abilities required by safari staff to successfully interact with hunters during the delivery of the core service. Supporting services described those service attributes that were not essential for the delivery of the core service, but acted as value-added elements to make the package more attractive and competitive. Since the reliability analysis supported the internal consistency of all three factors, it can be argued that, from a methodological point of view, the ASO model can be used to determine U.S. hunters' perceptions of the South African hunting safari.

In addition to the methodological value of the research, South African safari providers can also use the ASO-based measuring instrument to help identify those areas where service expectations are not met. Six points of failure were identified; namely, abundance of game, knowledgeable staff, well-trained staff, staff's ethical standards, 'wilderness feeling' of facilities and a sincere interest in solving clients' problems. Five of these items formed part of the core service. Safari providers could attempt to close these gaps by attending to the training and empowerment of their staff. In addition they could also enter into in-depth discussions with clients on their expectations and perceptions of the troublesome service elements. The results can inform the focus of staff training and strategies for closing the service failure gaps.

Safari service providers can similarly use the ASO-model to identify areas of over-delivery. While overdelivery on customers' expectations is likely to add additional burdens on the service provider, excessive levels of delivery might not necessarily result in higher levels of satisfaction, progressively more favorable word-of-mouth or make a major difference to clients' intention to return.

Our second research objective concerned the quality-satisfaction and quality-intention links in a hunting context. U.S. hunters were generally satisfied with their South African safari despite the above average expectation scores. Only core service was found to have a significant effect on satisfaction. The hunters had strong intentions to return to South Africa for another hunting safari. While no reliable correlation between perceived service quality and revisit intentions could be found, both core and supporting services made a statistically significant contribution to the prediction of revisit intention. U.S. hunters also planned to recommend South Africa as a hunting safari destination. Core services, facilitating services, and supporting services made a significant contribution to the prediction of word-of-mouth referrals.

Our results thus showed that core service was the only quality factor that had a significant effect on both 
satisfaction and behavioral intentions. However, this was also the factor with the most service failures. South African safari providers should thus pay special attention to core services when thinking about the sustainability of their businesses.

This research made a contribution to a better understanding of the quality of the South African hunting safari and heeded the call for more confirmatory studies on the ASO model. Given that, to our knowledge, this was the first attempt at applying this model in a hunting safari context, future research might want to verify the applicability of the Basic Service Package elements of the ASO model to other hunter groups (e.g. European hunters) participating in the South Africa safari, other hunting types (e.g. meat hunting), and other hunting destinations. Future research may also want to verify the usefulness of the ASO model in other wildlife or naturebased tourism contexts, such as archery and watersports. However, a set of service attributes unique to the specific tourist activity will be required.

\section{ACKNOWLEDGEMENTS}

This material is based upon work supported financially by the National Research Foundation (NRF), South Africa. Any opinions, findings and conclusions or recommendations are those of the authors. The NRF does not accept any liability in regard thereto.

\section{AUTHOR INFORMATION}

Xiliang Han is a contract research assistant in the Department of Marketing Management, Nelson Mandela Metropolitan University where he was awarded a Bachelor and a Masters degree in Marketing (Cum Laude). He won various institutional-level academic honors, including the Vice-Chancellor's Award: Best Postgraduate Student for 2009 (Social Sciences and Humanities); Council Award: Best Master's in Technology by Dissertation Graduate for 2009 (Social Sciences and Humanities); and Council Award: Best Baccalaureus Technologiae Graduate for 2007. His current research focuses on service and experience aspects in tourism.

Laetitia Radder is a senior professor in the Department of Marketing Management, Nelson Mandela Metropolitan University, Port Elizabeth, South Africa. She has published in various journals, both local and international. She has also received a number of awards for excellence in research. Her research interests include service and experience aspects in tourism.

\section{REFERENCES}

1. Akama, J.S. and Kieti, D.M. (2003). Measuring tourist satisfaction with Kenya's wildlife safari: A case study of Tsavo West National Park. Tourism Management, 24(1), 73-81.

2. Akbaba, A. (2006). Measuring service quality in the hotel industry: A study in a business hotel in Turkey. Hospitality Management, 25, 170-192.

3. Atilgan, E., Akinci, S. and Aksoy, S. (2003). Mapping service quality in the tourism industry. Managing Service Quality, 13(5), 412-422.

4. Babakus, E. and Boller, G.W. (1992). An empirical assessment of the SERVQUAL scale. Journal of Business Research, 24(3), 253-268.

5. Baker, D.A. and Crompton, J.L. (2000). Quality, satisfaction and behavioral intentions. Annals of Tourism Research, 27(3), 785-804.

6. Baron, S., Harris, K. and Hilton, T. (2009). Services Marketing: Text and Cases. New York: Palgrave Macmillan.

7. $\quad$ Burns, A.C. and Bush, R.F. (2006). Marketing Research. Upper Saddle River: Pearson.

8. Buttle, F. (1996). SERVQUAL: Review, critique, research agenda. European Journal of Marketing, 30(1), 8-32.

9. Carman, J.M. (1990). Consumer perceptions of service quality: An assessment of the SERVQUAL dimensions. Journal of Retailing, 66(1), 33-55.

10. Caro, L.M. and García, J.A.M. (2008). Developing a multidimensional and hierarchical service quality model for the travel agency industry. Tourism Management, 29, 706-720.

11. Chand, M. (2010). Measuring the service quality of Indian tourism destinations: An application of 
SERVQUAL model. International Journal of Services Technology and Management, 13(3/4), 218-233.

12. Chen, C. (2008). Investigating structural relationships between service quality, perceived value, satisfaction, and behavioral intentions for air passengers: Evidence from Taiwan. Transportation Research Part A, 42, 709-717.

13. Chi, C.G. and Qu, H. (2008). Examining the structural relationships of destination image, tourist satisfaction and destination loyalty: An integrated approach. Tourism Management, 29(4), 624-636.

14. Coye, R.W. (2004). Managing customer expectations in the service encounter. International Journal of Service Industry Management, 15(1), 54-71.

15. Crompton, J.L. and Love, L.L. (1995). The predictive validity of alternative approaches to evaluating quality of a festival. Journal of Travel Research, 34(1), 11-24.

16. Cronin, J.J., Brady, M.K. and Hult, G.T.M. (2000). Assessing the effects of quality, value, and customer satisfaction on consumer behavioral intentions in service environments. Journal of Retailing, 76(2), 193218.

17. Cronin, J.J. and Taylor, S.A. (1992). Measuring service quality: A re-examination and extensions. Journal of Marketing, 56(July), 55-68.

18. Damm, G.R. (2005). Hunting in South Africa: Facts, risks, opportunities. African Indaba, 3(4/5), 1-23.

19. Dillon, W.R., Madden, T.J. and Firtle, N.H. (1994). Marketing Research in a Marketing Environment. Burr Ridge: Irwin.

20. Donne, K. (2009). ADVENTUREQUAL: An extension of the SERVQUAL conceptual gap model in young people's outdoor adventure. International Journal of Sport Management and Marketing, 6(3), 253-276.

21. Frochot, I. and Hughes, H. (2000). HISTOQUAL: The development of a historic houses assessment scale. Tourism Management, 21(2), 157-167.

22. Getty, J.M. and Getty, R.L. (2003). Lodging quality index (LQI): Assessing customers' perceptions of quality delivery. International Journal of Contemporary Hospitality Management, 15(2), 94-104.

23. Gilbert, D. and Wong, R.K.C. (2003). Passenger expectations and airline services: A Hong Kong based study. Tourism Management, 24, 519-532.

24. Gounaris, S. (2005). Measuring service quality in b2b services: An evaluation of the SERVQUAL scale vis-à-vis the INDSERV scale. Journal of Services Marketing, 19(6), 421-435.

25. Grönroos, C. (1984). A service quality model and its marketing implications. European Journal of Marketing, 18(4), 36-44.

26. Grönroos, C. (1987). Developing the service offering: A source of competitive advantage. In Add Value to Your Service: The Key to Success, Surprenant, C. (ed), 81-85. San Diego: American Marketing Association.

27. Grönroos, C. (2007). Service Management and Marketing: Customer Management in Service Competition. Chichester: John Wiley \& Sons.

28. Grönroos, C., Heinonen, F., Isoniemi, K. and Lindholm, M. (2000). The NetOffer model: A case example from the virtual marketspace. Management Decision, 38(4), 243-252.

29. Hair, J.F., Black, W.C., Babin, B.J., Anderson, R.E. and Tatham, R.L. (2006). Multivariate Data Analysis. Upper Saddle River: Pearson.

30. Hair, J.F., Bush, R. and Ortinau, D. (2006). Marketing Research within a Changing Information Environment. New York: McGraw-Hill.

31. Hall, C.M. and Boyd, S. (2005). Nature-based tourism in peripheral areas: Introduction. In Nature-based Tourism in Peripheral Areas: Development or Disaster? Hall, C.M. and Boyd, S. (eds), 3-20. Clevedon: Channel View Publications.

32. Hamman, K.C.D., Lloyd, P.H. and Stadler, J.C. (2005). Hunting as an Acceptable Management Tool for Conservation. Retrieved from: www.africaindaba.co.za/Discussion/hunting.htm, 27 September 2009.

33. Hoffman, K.D. and Bateson, J.E.G. (2006). Services Marketing: Concepts, Strategies, \& Cases. Mason: Thomson Higher Education.

34. Hsu, C., Killion, L., Brown, G., Gross, M.J. and Huang, S. (2008). Tourism Marketing: An Asia-Pacific Perspective. Brisbane: John Wiley \& Sons.

35. Hui, T.K., Wan, D. and Ho, A. (2007). Tourists' satisfaction, recommendation and revisiting Singapore. Tourism Management, 28(4), 965-975. 
36. Hutchinson, J., Lai, F. and Wang, Y. (2009). Understanding the relationships of quality, equity, satisfaction, and behavioral intentions among golf travelers. Tourism Management, 30, 298-308.

37. Khan, M. (2003). ECOSERV: Ecotourists' quality expectations. Annals of Tourism Research, 30(1), 109124.

38. Kouthouris, C. and Alexandris, K. (2005). Can service quality predict customer satisfaction and behavioral intentions in the sport tourism industry? An application of the SERVQUAL model in an outdoor setting. Journal of Sport Tourism, 10(2), 101-111.

39. Ladhari, R. (2008). Alternative measures of service quality: A review. Managing Service Quality, 18(1), 65-86.

40. Lehmann, D.R. (2006). Using regression to answer "what if". In The Handbook of Marketing Research: Uses, Misuses, and Future Advance, Grover, R. and Vriens, M. (eds), 255-266. Thousand Oaks: Sage.

41. López-Toro, A.A., Dỉaz-Muñoz, R. and Pérez-Moreno, S. (2010). An assessment of the quality of a tourist destination: The case of Nerja, Spain. Total Quality Management, 21(3), 269-289.

42. Masmanidis, T., Vassiliadis, C. and Mylonakis, J. (2006). Evaluation of Ski Center services in Greece based on the multi attribute measurement model of attitudes. Journal of Social Sciences, 2(3), 81-84.

43. Mauser, G. and Paddon, R. (2000). Placing Hunting in Perspective. Washington, DC: Wildlife Management Institute.

44. Mudie, P. and Pirrie, A. (2006). Services Marketing Management. Oxford: Butterworth-Heinemann.

45. Normann, R. (2000). Service Management: Strategy and Leadership in Service Business. Chichester: John Wiley \& Sons.

46. Nyaupane, G.P., Morais, D.B. and Graefe, A.R. (2004). Nature tourism constraints: A cross-activity comparison. Annals of Tourism Research, 31(3), 540-555.

47. Oh, H. (2001). Revisiting importance-performance analysis. Tourism Management, 22, 617-627.

48. Oliver, R.L. (1980). A cognitive model of the antecedents and consequences of satisfaction decisions. Journal of Marketing Research, 17(November), 460-469.

49. Ozment, J. and Morash, E. (1994). The augmented service offering for perceived and actual service quality. Journal of the Academy of Marketing Science, 22(4), 352-363.

50. Pallant, J. (2007). SPSS Survival Manual. Berkshire: Open University Press.

51. Parasuraman, A., Zeithaml, V. and Berry, L. (1988). SERVQUAL: A multiple-item scale for measuring consumer perceptions of service quality. Journal of Retailing, 64(1), 12-40.

52. Parasuraman, A., Zeithaml, V. and Berry, L. (1994). Reassessment of expectations as a comparison standard in measuring service quality: Implications for future research. Journal of Marketing, 58(1), 111124.

53. Petrick, J.F. (2004). The roles of quality, value, and satisfaction in predicting cruise passengers' behavioral intentions. Journal of Travel Research, 42(May), 397-407.

54. Professional Hunters' Association of South Africa. (2009). General Hunting Information. Retrieved from: www.phasa.co.za, 27 September 2009.

55. Professional Hunters' Association of South Africa. (2010). General Hunting Information. Retrieved from: www.phasa.co.za, 12 August 2010.

56. Radder, L. (2003). A Profile of the International Hunter: Research Report. Port Elizabeth: Port Elizabeth Technikon.

57. Reisinger, Y. and Turner, L.W. (2003). Cross-cultural Behaviour in Tourism: Concepts and Analysis. Oxford: Butterworth-Heinemann.

58. Report to the Minister of Environmental Affairs and Tourism. (2005). Final Draft Report by the Panel of Experts of Professional and Recreational Hunting in South Africa. Retrieved from: www.africanindaba.co.za, 11 November 2005.

59. Sanghera, J., Chernatony, L. and Brown, A. (2002). Testing Grönroos's model in the financial services sector. The Service Industries Journal, 22(3), 1-14.

60. Schiffman, L.G. and Kanuk, L.L. (1987). Consumer Behavior. Englewood Cliffs: Prentice-Hall.

61. Smith, N.J. and Martins, J.H. (1996). Primary research: Written communication. In Marketing Research: A South African Approach, Martins, J.H., Loubser, M. and Van Wyk, H de J. (eds), 148-167. Pretoria: Unisa Press.

62. Stevens, P., Knutson, B. and Patton, M. (1995). DINESERV: A tool for measuring service quality in restaurants. Cornell Hotel and Restaurant Administration Quarterly, 36(2), 56-60. 
63. Teas, R.K. (1993). Expectations, performance evaluation, and consumers' perceptions of quality. Journal of Marketing, 57(October), 18-34.

64. Tse, D.K. and Wilton, P.C. (1988). Models of customer satisfaction: An extension. Journal of Marketing Research, 25, 204-212.

65. Van der Waal, C. and Dekker, B. (2000). Game ranching in the Northern Province of South Africa. South African Journal of Wildlife Research, 30(4), 151-156.

66. Von Brandis, R.G. and Reilly, B.K. (2007). A temporal analysis of trophy quality in South Africa: Has trophy quality changed over time? South African Journal of Wildlife Research, 37(2), 153-158.

67. Williams, C. and Buswell, J. (2003). Service Quality in Leisure and Tourism. Oxford: CABI Publishing.

68. Yuan, J. and Jang, S. (2008). The effects of quality and satisfaction on awareness and behavioral intentions: Exploring the role of a wine festival. Journal of Travel Research, 46(February), 279-288.

69. Žabkar, V., Brenčič, M.M. and Dmitrović, T. (2010). Modelling perceived quality, visitor satisfaction and behavioural intentions at the destination level. Tourism Management, 31, 537-546.

70. Zeithaml, V.A., Berry, L.L. and Parasuraman, A. (1993). The nature and determinants of customer expectations of service. Journal of the Academy of Marketing Science, 21(1), 1-12.

71. Zeithaml, V.A., Berry, L.L. and Parasuraman, A. (1996). The behavioral consequences of service quality. Journal of Marketing, 60, 31-46.

72. Zeithaml, V.A. and Bitner, M.J. (2000). Services Marketing: Integrating Customer Focus across the Firm. New York: McGraw-Hill. 
NOTES 